\title{
The evolution of concentration in the arms market
}

\section{J. Paul Dunne and Ron P. Smith}

J. Paul Dunne is Professor of Economics, Department of Economics, University of Cape Town, Cape Town, South Africa. The corresponding author, he can be reached at john.dunne@uct.ac.za. Ron P. Smith is Professor of Economics, Department of Economics, Mathematics, and Statistics, Birkbeck College, University of London. He can be reached at r.smith@econ.bbk.ac.uk.

\section{Abstract}

This paper examines the evolution of concentration in the global arms market, or industry, over the period 1990-2013 and considers its prospects. Using data from the Stockholm International Peace Research Institute (SIPRI) list of the largest 100 arms producing firms, it finds that within the international arms industry, there has been change but also continuity, particularly in the nature of the markets and the relations between the main producers and governments. While the changes that have taken place are important, it is still political rather than economic logic that shapes the evolution of the market. Certainly the arms industry remains relatively unconcentrated compared to other industries probably because of the domestic preferences in procurement by national governments. Countries do not like monopoly arms producers, but there is no western country other than the United States that can currently support more than one competitor, although in the near future Russia could and China may provide serious international competition to the U.S. What is clear is that there are economic forces pushing for increased competition, but the final outcome will be determined by political forces, and transparency and governance will become increasingly important issues.

$\mathrm{T}$ his article examines the evolution of concentration in the global arms market, or industry, over the period 19902013. It uses data from the Stockholm International Peace Research Institute's (SIPRI) annual listing of the largest 100 arms producing firms. This list is a very valuable resource for analyzing the market, and researchers must be grateful for this asset. Although we use SIPRI's definition of the market, we recognize the difficulty of defining the arms market in terms of the usual criteria for defining an industry, or market, in terms of product, use, or geographical space. While the industry's products might appear quite heterogeneous (e.g., aircraft, tanks, or ships), they may be substitutable in use and Ministries of Defense (MoDs) need to determine the right mix of products for the appropriate application of force. However, their use is not unambiguous and purchase by MoDs is not a defining characteristic. MoDs also are major users of oil and petroleum products, which can account for a substantial part of their budgets, yet these are not normally regarded as part of the arms market, and similar comments apply to a variety of dual-use products. Additionally, MoDs purchase services from private companies, including private military companies, which are taking an increasing part of their defense budget as well. These companies now are being included in the SIPRI list.

For some products in some countries, the arms market is purely national, as the relevant $\mathrm{MoD}$ would not purchase from abroad, but even here there may be potential substitution. Even the United States, the most arms self-reliant country, purchases weapons on the global market. For other purposes, narrower definitions of the market may be useful, but here we use a wide definition. Inevitably, there are omissions. In particular, SIPRI does not include data on Chinese companies and the information on some other countries is limited.

There is a large literature on the arms industry. Dunne (2009) discusses the evolution of the concentration in the arms industry, which at the end of the cold war era was very low. Dunne (1995), Brauer (2007), and Hartley (2007) have general discussions of the industry. Reviews of the structure of the industry are given in Smith $(1990 ; 2001 ; 2013)$. There are also studies of the industries in individual countries. Recent examples are Caruso and Locatelli (2013) on Italy and Mauro and Oudot (2014) on France. There are, however, considerable changes taking place in the industry, in terms of its structure, composition, and spatial characteristics, and so it is useful to have an updated analysis. This article provides this.

The next section considers arms industry dynamics, such as demand and supply side issues and the changes that occurred with the end of the cold war. This is followed by an analysis of the changes in concentration in the international arms industry since 1990, using Herfindahl-Hirschman indices. We then consider the size distribution of arms companies using power law representations. The final section presents some conclusions and considers the prospects for the industry. 
Table 1: Top arms producing companies, 2012-2013 (sales in billions of USD; military sales share as percent of total sales)

$\begin{array}{lccc}\text { Company } & 2012 & 2013 & \text { Share (\%) } \\ \text { Lookheed Martin (US) } & 36.0 & 35.5 & 78 \\ \text { Boeing (US) } & 27.6 & 30.7 & 35 \\ \text { BAE Systems (UK) } & 26.8 & 26.8 & 94 \\ \text { Raytheon (US) } & 22.5 & 21.9 & 93 \\ \text { Northrop Grumman (US) } & 19.4 & 20.2 & 82 \\ \text { General Dynamics (US) } & 20.9 & 18.7 & 60 \\ \text { EADS (Airbus) (EU) } & 15.4 & 15.7 & 20 \\ \text { United Technologies (US) } & 13.5 & 11.9 & 19 \\ \text { Finmeccanica (IT) } & 12.5 & 10.6 & 50 \\ \text { Thales (FR) } & 8.9 & 10.4 & 55 \\ \text { Source: SIPRI. } & & & \end{array}$

\section{Arms industry dynamics}

Arms firms are often national champions who have a monopoly in arms production, giving the incumbent a clear advantage over outsiders considering market entry. Barriers to market entry, and exit, are important and the list of companies has been surprisingly stable. Despite the recent restructuring of defense prime contractors (the primes) and there being some mergers, the names of the top companies remain evident: Boeing, BAE, Northrop Grumman, and so, as shown in Table 1.

The evolution of the industry is driven by demand and supply forces. Demand depends on the size of the market, the level of military expenditure, itself a function of income (GDP) and perceived threats, the split of expenditure among new equipment, personnel, maintenance, and budget distribution over products and countries. On the supply side, a dialectical interaction exists between pressures for internationalization and pressures for nationalization to maintain domestic production. In production, large fixed costs, learning curves, and economies of scale make minimum efficient scales large and so provide incentives to internationalize. Yet states wish to maintain national technological autonomy and a defense industrial base to ensure security of supply for weapons. States also face tension between promoting competition to reduce prices in the face of the high fixed costs and economies of scale that promote monopoly. States are always actors in the arms industry as they buy arms, determine the quality/quantity mix of domestic
This article examines the evolution of the global arms industry, in particular in regard to firm concentration ratios. It is found that while the industry tends to follow the predicted power law distribution, for its size, the industry still lags behind civilian industry in terms of the expected degree of global concentration.

production, pay for $\mathrm{R} \& \mathrm{D}$, license exports for strategic or other reasons, and often own defense firms, e.g., in France. A theoretical model of the determination of the defense industrial base and the size of the arms industry is provided in Dunne, et al. (2007).

On the demand side, military expenditure and arms exports peaked in the mid-1980s, then fell gradually at first, then more rapidly with the disintegration of the Soviet Union. Arms trade halved from the mid-1980s to the mid-1990s. The decline in military expenditure bottomed out in the late 1990s. Post-9/11, however, the Global War on Terror led by the United States resulted in military expenditure increasing again and reinforced the U.S. dominance of world military expenditure. At around the time of the 2008 global financial crisis, the U.S. accounted for 40 percent of the world total. Austerity measures in Europe and elsewhere, and the withdrawal from Afghanistan and Iraq, then reduced military expenditure, but growth in military expenditure emerged in other world regions, such as Asia and Russia.

The end of the cold war era produced not just a quantitative change in the amount of weaponry but a qualitative change in the type of weapons required. The Revolution in Military Affairs, which emphasized network-centric warfare and asymmetric conflict, changed the technology requirements of weapons systems and was associated with changes from technology spin-offs (to civilian markets) to spin-ins (from civilian markets). This recognized the advancement of civil technologies beyond military technology in many areas and led to the sourcing of major components and systems from civil companies, and company takeovers, to gain technological capabilities. In the United Kingdom, this is referred to as the use of civil-off-the-shelf technology.

The reduction in demand at the end of the cold war prompted a variety of corporate responses on the supply side, as reviewed in Smith and Smith (1992). Firms divested their military assets and converted or diversified to civilian activities, cooperated, merged, or took over competitors and internationalized. The financial system aided the mergers and acquisition process, and the U.S. government subsidized it. Although the primes might appear national champions, the supply chains were in fact international and even countries that appeared to import little, like the U.S., had many imported 


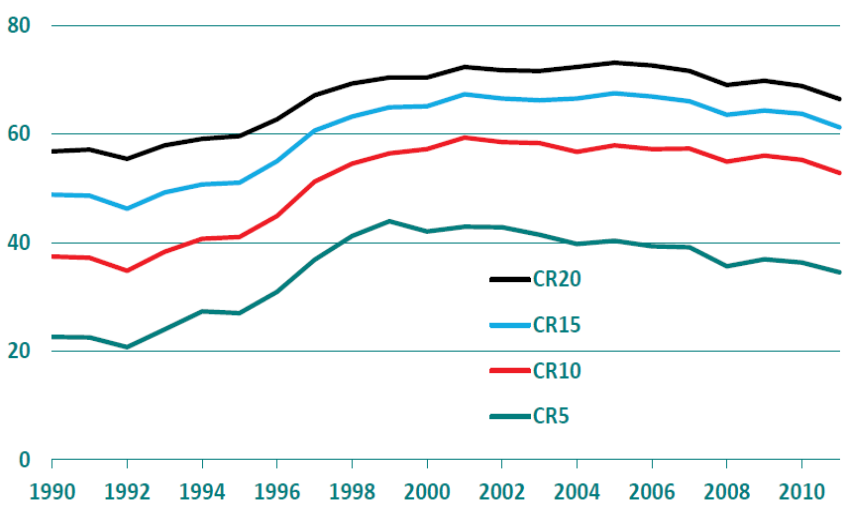

Figure 1: Arms industry concentration, 1990-2011 (market share as percentage of total market with $n=100$ firms). Source: Computed from SIPRI arms company database.

components in their systems. European restructuring was different, in part because of the involvement of domestic governments, but consolidation still happened to some degree. Increasingly, company restructuring has to be seen in conjunction with other states: allies, suppliers, collaborative production, and so on (Dunne, 2009).

\section{Concentration}

As noted, treating the international arms industry as an undifferentiated entity in itself is not without question. Defining the relevant market boundaries is difficult and the analysis here is restricted to data collected on the top-100 companies. Not only are there cross-country compositional concerns, but there are also problems on where the arms industry starts and ends. Different definitions and limits to data availability can lead to problems in aggregation and in composition. There is also a further composition effect in that the industry strongly depends on relative military expenditure, wherefore the demand side is dominated by U.S. spending.

A widely used measure of industry concentration is the Herfindahl-Hirschman Index (HHI). This is constructed by first ranking the top-100 companies by size, for example, as measured by arms sales $A_{i} ; i=1,2, \ldots, 100$, and calculating each firm's share as

(1) $s_{i}=A_{i} / \sum_{i=1}^{100} A_{i}$.

The $N$-firm concentration ratio is given by $\sum_{1}^{N} s_{i}$ and the Herfindahl-Hirschman Index, HHI, then is

(2) $H H I=\sum_{1}^{100} s_{i}^{2}$.

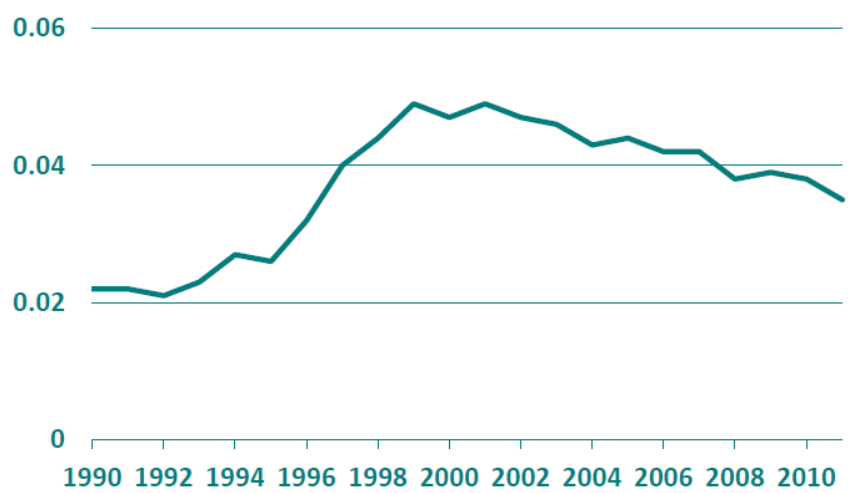

Figure 2: HHI scores $(\max =1.0)$ for arms sales and total sales of top-100 arms producing companies 1990-2011.

The U.S. Department of Justice, DoJ, regards an HHI of $0.15-0.25$ as moderately concentrated and an HHI over 0.25 as highly concentrated. The inverse, $1 / \mathrm{HHI}$, can be interpreted as the number of equivalent firms, so an HHI of 0.25 would be 4 equivalent firms. The HHI is sometimes calculated on the basis of percentage shares rather than proportionate shares.

Figure 1 presents the share of the top arms producers 1990-2011. The market share of the top-5 firms went up from 22 to a peak of 43 percent in 1999 and then declining to 35 percent by 2011 . The top- 20 share went from 58 to a high of 74 percent before declining to 68 percent. The other measures move broadly in line.

For the period 1990-2001, the concentration index, the HHI, more than doubled for arms sales, from 0.02 to 0.05 , before declining again (Figure 2). In 2011, the HHI was similar to 1996, at 0.035 , or about 28 equivalent firms. By DoJ criteria, this is a very low level of concentration, although for particular products, like fast jets, concentration would be higher.

SIPRI also gives data for total sales, rather than only armsrelated sales, for the companies that it identifies as arms firms. The HHI for total sales is higher than for arms sales. This again shows that arms sales are less concentrated than civilian sales.

The pattern of restructuring identified in the previous section is clearly evident in the HHI-concentration numbers for the top-100 arms producers, in both arms sales and total sales. Concentration rose sharply following the end of the cold war when world military expenditure fell. Then concentration fell again when defense spending rose after 9/11. In the United States, a big increase in concentration occurred between the 1993 "Last Supper" event — when then-Deputy Secretary of Defense William Perry encouraged defense industry CEOs to merge their firms - and the 1997 block on a proposed Lockheed-Northrop merger.

To get some idea of the concentration of the industry, 

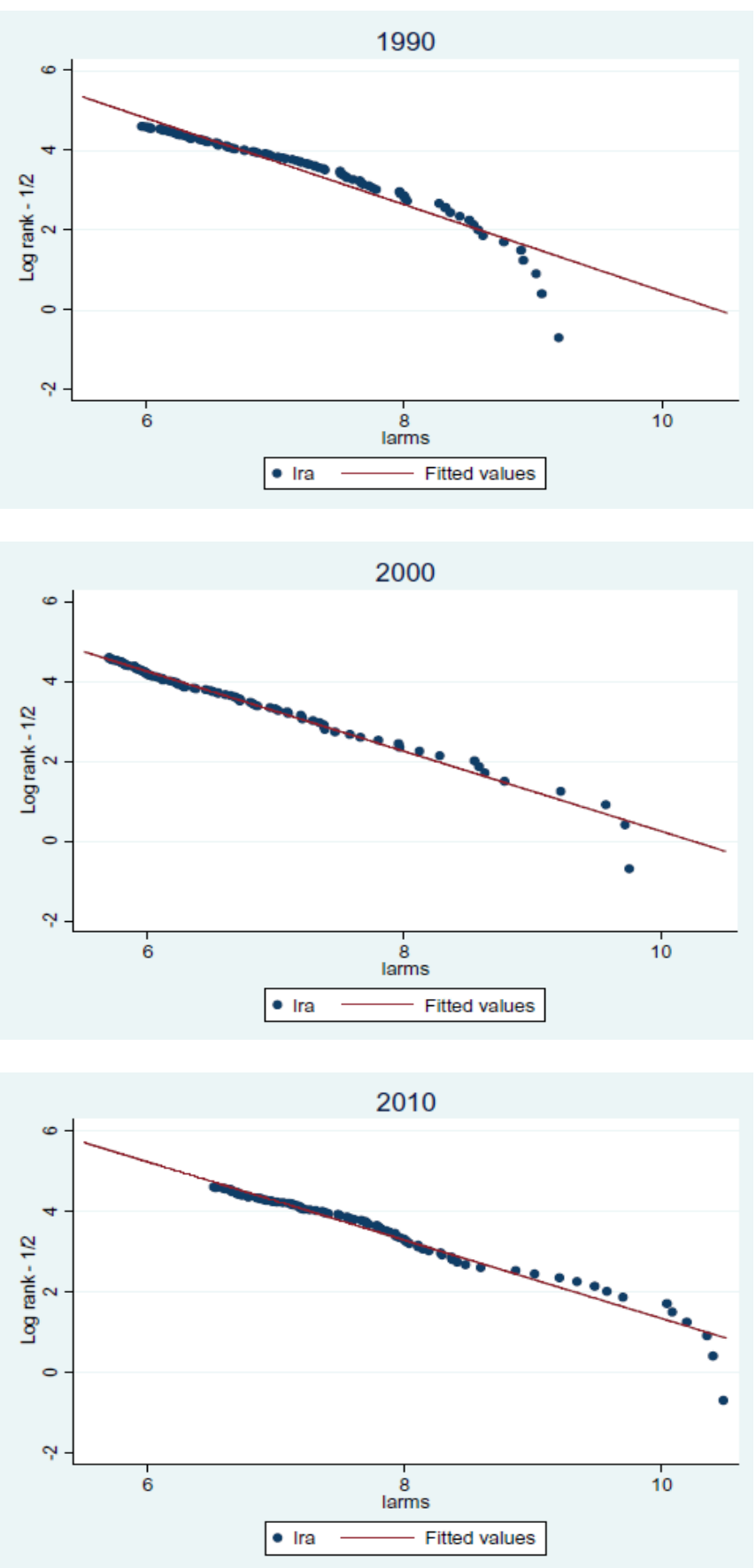

Figure 3: Arms industry power laws, selected years. Source: SIPRI arms company database.

Sutton (1991) provides a benchmark for industries consisting of submarkets. The arms industry is made up of many different types of submarkets such as for different types of weapons systems and for different countries. The Sutton lower bound of 20 percent for the share of the top-5 producers, C5, is only just below the 22 percent observed in 1990 for the arms industry. Thus, concentration in the this industry is not very high as
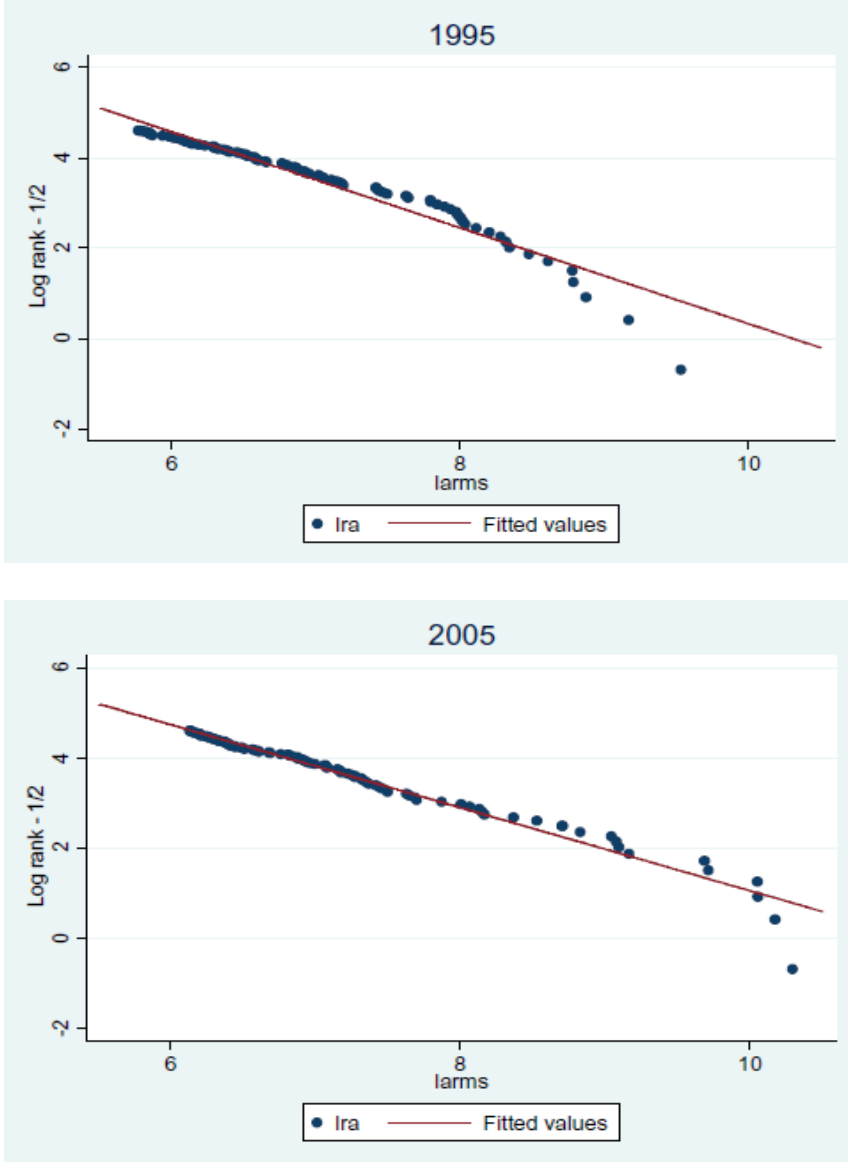

compared to industries with similar cost structures, e.g., civil aircraft or pharmaceuticals. Partly this is because unlike most manufacturing industries, which went multinational, the arms industry remained national.

To get a better idea of changes in the size distribution of the companies, an equivalent representation is to plot the log rank against log arms sales (Figure 3, for selected years). This shows how rank rises as firm sales rise and again illustrates that sales are higher among the top-ranked firms relative to what would be predicted from each of the fitted values lines. This is in fact a similar feature for all firms, but somewhat more marked for the arms industry. This distribution can be summarized using a power law regression. (Power laws or Pareto distributions occur for many phenomena such as city size, business size, income, or wealth.) The relationship between firm rank $(R)$ and size $(S)$ can be written as

(3) $R=A S^{b}$.

A special case is Zipf's law, where $b=|1|$, coming from linguist Zipf's observation that the frequency of any word in a language is in proportion to its rank in the frequency table. The most frequently used word (rank 1) occurs twice as often as the 
$-0.8$

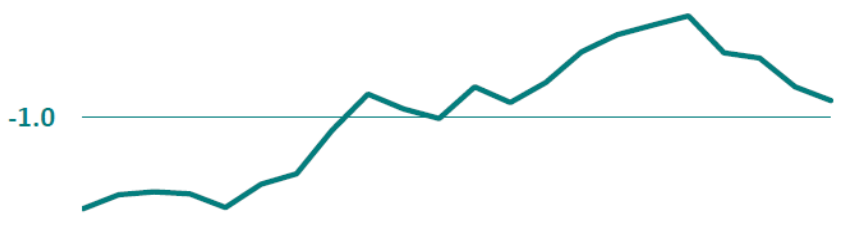

$-1.2$

19901992199419961998200020022004200620082010

Figure 4: Evolution of the $b$ coefficient.

second most frequently used word, and so on. This does seem to work well for the distribution of firm size as well, but there is a downward bias on estimation which has been dealt with by using the Gabaix and Ibragimov (2011) correction and estimating

(4) $\ln \left(R_{i}-1 / 2\right)=a+b \ln S_{i}+u_{i}$,

where $S_{i}$ is arms sales of the firm ranked $R_{i}$.

If $b=|1|$ then the distribution fits the Zipf distribution; if $b>|1|$ there is a tendency for concentration to larger firms; and if $b<|1|$ there is a tendency for concentration to smaller firms. This last result implies that size diminishes less than the quotient between the largest firm and the rank a firm occupies. In general, the size distribution of firms tends to follow the distribution with an exponent of about 1.06 (Gabaix, 2016).

A useful way of seeing the change over time is to consider the evolution of the $b$ coefficient. Thus, Figure 4 shows a clear change in the coefficient value from above to below (absolute) one, with the transition taking place in the early 2000s. In the late 2000s, it declines again and is close to 1 by 2011. Looking at the distributions for selected years, 1990, 1995, 2000, 2005, and 2010, in Figure 3, one notices that the break-away from the fitted lines at the highest arms sales levels is relatively consistent over time and that while concentration changed, the pattern at the top ranks did not. (To get a sense of how the structure of the arms industry differs from industry in general one can refer to Luttmer, 2007, which considers how well cumulative employment in the U.S. is approximated by gamma and lognormal distributions. His work suggests that, except for the largest international arms-industry firms, a similar distribution applies.)

A clear pattern thus emerges, with the expected changes in arms industry concentration following rises and falls in demand in an industry with high fixed costs, but what happened was rather large. Concentration peaked in the early 2000s. Although it has declined since then, it is not back to the relatively low concentration level of the early-1990s. The fall in R\&D was less than the decline in military spending, so fixed costs have risen for the industry.

Despite the increase in concentration that has occurred, the nature of market is such that it should be more concentrated and more multinational than it currently is. Even if one looks at narrow categories, military production tends to be much less concentrated than civilian production. For instance, there are more manufacturers of fast military jet aircraft than of large civil aircraft.

It is likely that national governments' policies such as the blocking of the 2012 proposal to merge BAE and EADS, have restrained the tendency to higher concentration that would have resulted from the operation of market forces. Market forces, however, are likely to maintain the pressure toward concentration.

\section{Conclusion and prospects}

Within the international arms industry, there has been change but also continuity, particularly in the nature of the markets and the relations between the main producers and governments. While the changes that have taken place are important, it is still political rather than economic logic that shapes the evolution of the market. After the end of the cold war, the industry restructured, and it continues to do so, but there are differences to the initial trends. Certainly the arms industry remains relatively unconcentrated as compared to other industries, probably because of the domestic procurement preferences exerted by national governments. With the decline in demand after the cold war came a continued increase in R\&D intensity, representing fixed costs for the companies, and this led to increases in concentration. After the 9/11 attack on the United States, there was an increase in demand and a resulting reduction in concentration, but firm concentration is not yet back to the level of the 1990 s.

The U.S. arms industry is still dominant, but this is not the whole story and there are important differences between the U.S. and Europe that need further investigation. While the U.S. restructuring continues, the EU has been slower and restructuring still has some way to go. With the limited demand in Europe, there should be more focused and concentrated production, with some regions producing major weapon systems and with the rest involved in niche and supply chain production, but this is a long way off. The U.S. dominance remains and U.S. and European links have developed, but there are also important new global players, China and Russia most noticeably, but also the other two BRIC countries, Brazil and 
India. The industry has certainly internationalized, particularly in its supply chains.

While the primes still maintain dominance, a lot of new companies are entering the market. Some are being taken over by the primes to expand their capabilities and this may increase in the future. It is also noticeable that industrial sectors different from the "traditional" arms sectors are becoming increasingly involved as a result of changing technologies and outsourcing of military and related services by defense ministries. One implication is that parts of the military-industrial complex now have an active interest in conflict, rather than just in the production of arms (Dunne and Sköns, 2010).

What are the industry's prospects? There are still too many large companies, so there is continuing pressure to merge. But in 2012 the proposed EADS-BAE merger was stopped by the German government and so Europe has seen rather limited concentration. The U.S. has Lockheed, Northrop-Grumman, and Boeing competing, with Airbus and BAE Systems in the wings. Countries do not like monopoly arms producers, of course, but other than the U.S. there is no western country that can currently support more than one competitor. It is questionable whether domestic competition is still viable, even in the U.S. In the near future, Russia could, and China may, provide serious international competition to the United States.

One area where concentration would seem particularly likely is military aircraft production, where there are an unsustainably large number of companies, especially in Europe. If defense budgets become even more constrained, pressure to increase concentration will ramp up, but it is not clear that industry concentration will increase as it did in the 1990s, and it is an open question as to what the process of restructuring will be. The follow-on imperative operates to limit competition, and different national defense industrial bases have different styles, making international cooperation and restructuring difficult. What is clear is that there are economic forces pushing for increased competition, but the final outcome will be determined by political forces, and transparency and governance will become increasingly important issues.

\section{References}

Brauer, J. 2007. "Arms Industries, Arms Trade and Developing Countries,” pp. 973-1015 in T. Sandler and K. Hartley, eds. Handbook of Defense Economics. Vol. 2. Amsterdam: North-Holland.

Caruso, R. and A. Locatelli. 2013. "Finmeccanica Amid International Market and State Control: A Survey of the Italian Defence Industry." Defence and Peace Economics. Vol. 24, No. 1, pp. 89-104.

http://dx.doi.org/10.1080/10242694.2011.635952

Dunne, J.P. 1995. “The Defence Industrial Base,” pp. 592-623 in K. Hartley and T. Sandler, eds. Handbook of Defense Economics. Vol. 1. Amsterdam: North-Holland. http://dx.doi.org/10.1016/S1574-0013(05)80016-X

Dunne, J.P. 2009. "Developments in the Global Arms Industry from the End of the Cold War to the Mid-2000s, pp. 13-37 in R. Bitzinger, ed. The Modern Defense Industry: Political, Economic and Technological Issues. Westport, CT: Praeger.

Dunne, J.P., M. Garcia-Alonso, P. Levine, and R.P. Smith. 2007. "Determining the Defence Industrial Base." Defence and Peace Economics. Vol. 18, No. 3, pp. 199-222. http://dx.doi.org/10.1080/10242690600924273

Dunne, J.P. and E. Sköns. 2010. "Military Industrial Complex," pp. 281-292 in A. Tan, ed. The Global Arms Trade: A Handbook. London: Routledge.

Gabaix, X. 2016. "Power Laws in Economics: An Introduction." Journal of Economic Perspectives. Vol. 30, No. 1, pp. 185-206. http://dx.doi.org/10.1080/10242690600924273

Gabaix, X. and R. Ibragimov. 2011. "Rank-1/2: A Simple Way to Improve the OLS Estimation of Tail Exponents." Journal of Business and Economic Statistics. Vol. 29, No. 1, pp. 24-39. http://dx.doi.org/10.1198/jbes.2009.06157

Hartley, K. 2007. "The Arms Industry, Procurement and Industrial Policies," pp. 1139-1176 in T. Sandler and K. Hartley, eds. Handbook of Defence Economics. Vol. 2. Amsterdam: North Holland.

Luttmer, E.G.J. 2007. "Selection, Growth, and the Size Distribution of Firms." Quarterly Journal of Economics. Vol. 122, No. 3, pp. 18-22. http://dx.doi.org/10.1162/qjec.122.3.1103

Moura, S. and J.-M. Oudot. 2014. "Company Survey Series: An Overview of the Defense Industrial Base in France." Working paper. Nineteenth International Conference on Economics and Security, Grenoble.

SIPRI Yearbook. Various years. Armaments, Disarmament and International Security. Oxford, UK: Oxford University Press.

Smith, R.P. 1990. "Defence Procurement and Industrial Structure in the UK." International Journal of Industrial Organisation. Vol. 8, pp. 185-205. http://dx.doi.org/10.1016/0167-7187(90)90015-S

Smith, R.P. 2001. "The International Arms Industry." World Economics. Vol. 2, No. 3, pp. 155-166.

Smith, R.P. 2013. "The Defense Industry in an Age of Austerity." The Economics of Peace and Security Journal. Vol. 8, No. 1, pp. 18-22. http://dx.doi.org/10.15355/epsj.8.1.18

Smith, D. and R.P. Smith. 1992. "Corporate Strategy, Corporate Culture and Conversion: Adjustment in the Defence Industry." Business Strategy Review. Vol. 3, No. 2, pp. 45-58. http://dx.doi.org/10.1111/j.1467-8616.1992.tb00028.x

Sutton, J. 1991. Sunk Costs and Market Structure. Cambridge, MA: MIT Press. 